\title{
Assessment of Traditional Agroforestry Practices, Benefits and Constraints: The Case of West Hararghe Zone, Oromia National Regional State, South-eastern Ethiopia
}

\author{
Husen Yusuf ${ }^{*}$, Alemeyehu Beyene, Muktar Reshad, Mangistu Teshoma \\ College of Natural Resources and Environmental Science, Oda Bultum University, Chiro, Ethiopia
}

Email address:

hudhmabaci@gmail.com (H. Yusuf)

${ }^{*}$ Corresponding author

\section{To cite this article:}

Husen Yusuf, Alemeyehu Beyene, Muktar Reshad, Mangistu Teshoma. Assessment of Traditional Agroforestry Practices, Benefits and Constraints: The Case of West Hararghe Zone, Oromia National Regional State, South-eastern Ethiopia. Journal of Plant Sciences.

Vol. 8, No. 5, 2020, pp. 158-166. doi: 10.11648/j.jps.20200805.18

Received: August 12, 2020; Accepted: August 24, 2020; Published: October 14, 2020

\begin{abstract}
A study was conducted in west Hararghe zone with the main objectives of understanding various traditional Agroforestry practices and to identify reasons behind practicing and to prioritize major constraints related to traditional Agroforestry practices. (18) Peasant associations in 6 rural districts were selected by multistage sampling in which 600 household heads were selected using random sampling techniques. Qualitative data were generated by conducting household survey interviews, focus group discussions, key informant interview, and direct field observations were applied to secure additional data. Data were manipulated using suitable analytical software packages to calculate descriptive statistics, including percentages and frequency. A total of $478(79.7 \%)$ of smallholder farmers expressed interest in practicing traditional agroforestry in their farm plots, $122(20.3 \%)$ of the total had no single practices in their farm plots. The results of this study have shown that mixed intercropping $(44 \%)$, homegarden $(36 \%)$, trees on cropland $(31 \%)$, boundary planting $(25 \%)$, trees on soil conservation (18\%), multi-purpose woodlots $(17 \%)$ and trees on rangeland $(9 \%)$ are the common traditional agroforestry practices in the study area. The major benefits for planting tree species were for income, soil quality, food, shade, fuel wood, construction purpose, manure, fodder and medicinal purpose. On the other hand, lack of adequate seedlings availability, shortage of land, rainfall shortage, termite hazard and disease, animal browsing, shortage of labour and inadequate extension servicesare the major constraints recorded in the study areas. The study recommends the suggestions made to overcome difficulties of practicing traditional agroforestry in smallholders' farm plots have implications for the way forwarded.
\end{abstract}

Keywords: Traditional Agroforestry, Small Holder Farmers, Multipurpose Trees, Woody Species

\section{Introduction}

\subsection{Background to the Study}

According to World Agroforestry Center, agroforestry is a dynamic, ecological-based natural resources management system through integration of trees in to rangeland and farmland to diversify and sustain production for the increasing socio-economic and environmental benefits. Agroforestry is developed recently from the contraction of agriculture and forestry. As a land management system, it involves the introduction woody perennials, along with agricultural crops and pasture for domestic animals. Some of agroforestry systems in Ethiopia are farm forestry in the south-western highlands, tree based soil and water management in Konso, forest-based resources management in Borena, Ecologically sound land use system in Gedeo and area closures in Tigray, North Shoa and North Wello [9].

Examples of agroforestry practices are: tree homegarden, Woodlot, Windbreaks/shelterbelts, Boundary planting, Live fences, Hedgerow intercropping, improved fallow, Intercropping under scattered or regularly planted trees, Trees on rangelands, Trees on soil conservation and reclamation structures etc [8]. Integration trees into farmland, agroforestry helps to diversify income sustaining smallholder production for increased socioeconomic and environmental 
benefits. Serves as a buffer against increasing human and livestock population pressure, to pursue the scaling up of local efforts of maintaining trees in farm, to overcome the problem resulted from high dependence of the community on natural resource, to reduce the risks and increase the sustainability of both small and large-scale agriculture. They provide fuel wood for the household energy, building materials such as poles [16].

\subsection{Statement of the Problem}

In the management of agroforestry the traditional knowledge of local people is important, and in order to scale up the different agroforestry practices an appreciation of traditional knowledge is needed [25] and The existing farming system is the starting point for development [11]. Most development interventions in the past failed due to lack of giving adequate attention to traditional knowledge [18]. The future of agroforestry lies on the way researchers, workers, and policymakers understand the usefulness of the existing traditional agroforestry practices knowledge about trees in the traditional agroforestry. In Ethiopia, information, on traditional agroforestry practices is generated from limited studies $[2,17,4]$ and are more specific in terms of site, constraints and socioeconomic benefits [7, 19, 13, 1, 10]. These studies would not provide adequate information for better understanding of traditional agroforestry practices in West Hararghe zone.

There are several traditional agroforestry practices in different agro-ecological region of west Hararghe zone, but they are not well studied and documented. Besides to this the benefits of traditional Agroforestry practice on local community is not very much organized and identified specifically in the area. Collection of information on the existing agroforestry practices and identifying its constraints is a prerequisite for agroforestry research and development work in the study areas. The present study aimed at providing such information on available traditional knowledge for traditional Agroforestry, to identify reasons behind practicing agroforestry in the context of the farming system in study are and to identify major constraints related to traditional Agroforestry practices in the area.

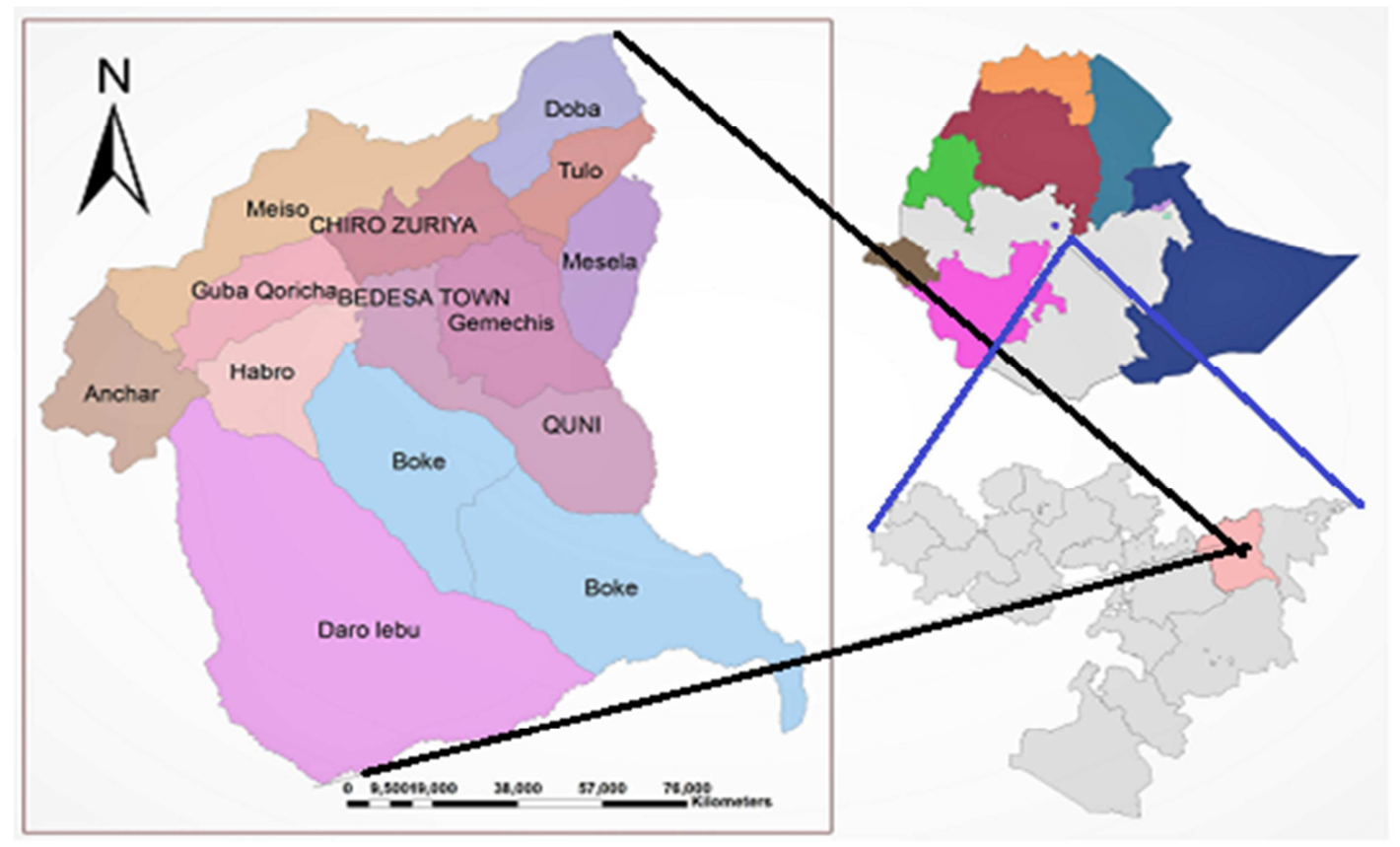

Figure 1. Map of study Area

\section{Research Methodology}

\subsection{Description of the Study Area}

West Harerghe Zone is one of the 17 Zones in Oromia National Regional State, geographically located between 70 52' 15"'-90 28' 43" North latitude and 400 03' 33"-400 34' 13" East longitudes. The zone is bordered in the South by the Shebelle River which separates it from Bale zone, on the Southwest by Arsi zone, on the Northwest by the Afar National Regional State, on the North by the Somali National Regional State and on the East by East Harerghe zone. Towns in West Harerghe include Chiro, Bedessa, Gelemso and Mieso. The capital town of the Zone is Chiro, which is located at a distance of $326 \mathrm{~km}$ East of Addis Ababa. The area coverage of the Zone is $1,723,145$ ha $(17,231 \mathrm{~km} 2)$, comprising of 15 districts with a combined population of $1,871,706$ persons, of whom 912,845 are women. While 160,895 or 9.36 percent are urban inhabitants, a further 10,567 or 0.56 percent are pastoralists and semi-pastoralists West Harerghe is subdivided in to three major climatic zones known to be temperate tropical highland, locally known as dega (12.49\%), semitemperate/tropical rainy mid land or woinadega $(38 \%)$, and semi-arid/tropical dry or kola (49.5\%) [24]. 


\subsection{Methods of Data Collection and Source}

Data was collected from household interviews, key informant interviews, focal group discussion and direct field observation (Table 2). The criteria of selecting of sample districts and Kebeles is based on agro ecology and potential of traditional agroforestry practices. Accordingly, (Gemechis \& Hancar district) from Highland agroecology, (Darolabu \& Oda Bultum district) from Midland dega agroecology and (Mieso \& Burkadhimtu district) from Lowland agroecology were selected.

Thus, informants were selected by applying the sample determination formula

$$
\mathrm{n}=\frac{\mathrm{z}^{2} \mathrm{pq}}{\mathrm{d}^{2}}
$$

to the 139,426 households [12] living in the six administrative districts of western Hararghe zone. Where $\mathrm{d}=0.05$ as the administrative districts were not of equal size and the $96 \%$ degree of confidence was converted the confidence level to a $\mathrm{Z}$ score which is 1.96 and confidence. We expected 50 percent respondents to respond affirmatively since such kind of research is never conducted previously in the area, 0.5 would be the proportion. We computed the needed sample size by plugging the values into the above formula, where $\mathrm{Z}$ is the $\mathrm{Z}$-score, $\mathrm{P}$ is the proportion and $\mathrm{d}$ is the confidence interval. Sample Size needed $=(1.96) 2 * 0.5(1-0.5) /$ $(0.04) 2=(3.8416 * 0.25) / 0.0016=0.9604 / 0.0016=$ 600.25

The calculated sample size was distributed to the six administrative districts by proportional allocation as given by

$$
\mathrm{n}_{\mathrm{h}}=\frac{\mathrm{nN}_{\mathrm{h}}}{\mathrm{N}}
$$

Where $\mathrm{n}=$ the total number of sample households, $\mathrm{N}_{\mathrm{h}}=$ total number of households in the administration zone, and $\mathrm{N}$ $=$ the total number of households in the overall study area, in six sample districts western Hararghe zone. This method has been recommended for research that depends somewhat on the relative costs of sampling more units compared with sampling more elements [15].

\begin{tabular}{|c|c|c|c|c|c|c|}
\hline Name of districts & $\begin{array}{l}\text { No. of rural peasant } \\
\text { associations }\end{array}$ & No. of sample $\mathbf{P A}^{*}$ & $\begin{array}{l}\text { Selected peasant } \\
\text { associations }\end{array}$ & PA total population & $\begin{array}{l}\text { No. of total peasant } \\
\text { associations HH }\end{array}$ & $\begin{array}{l}\text { No. of sampled } \\
\text { informants }\end{array}$ \\
\hline \multirow{3}{*}{ Gemechis } & \multirow{3}{*}{ a } & \multirow{3}{*}{3} & Sororo & 3666 & 607 & 43 \\
\hline & & & Madara & 5134 & 903 & 65 \\
\hline & & & Waltane & 2865 & 501 & 36 \\
\hline \multirow{3}{*}{ Hancar } & \multirow{3}{*}{38} & \multirow{3}{*}{3} & Dindin & 6381 & 1060 & 32 \\
\hline & & & Midhegdu & 3297 & 559 & 17 \\
\hline & & & Laftogoba & 2949 & 516 & 15 \\
\hline \multirow{3}{*}{ Darolabu } & \multirow{3}{*}{40} & \multirow{3}{*}{3} & Matagudesa & 3104 & 524 & 19 \\
\hline & & & Caffehara & 5641 & 926 & 34 \\
\hline & & & Kortu & 4587 & 814 & 29 \\
\hline \multirow{3}{*}{ OdaBultum } & \multirow{3}{*}{37} & \multirow{3}{*}{3} & Jawis & 5971 & 986 & 44 \\
\hline & & & Idobariso & 5900 & 973 & 43 \\
\hline & & & Odabaso & 4492 & 787 & 35 \\
\hline \multirow{3}{*}{ Mieso } & \multirow{3}{*}{35} & \multirow{3}{*}{3} & Husehadami & 3256 & 542 & 29 \\
\hline & & & Hundemisoma & 4541 & 726 & 39 \\
\hline & & & Husemandhera & 3564 & 608 & 33 \\
\hline \multirow{3}{*}{ Burkadimtu } & \multirow{3}{*}{36} & \multirow{3}{*}{3} & Tayfe & 4028 & 692 & 30 \\
\hline & & & Rukesaifa & 4262 & 725 & 31 \\
\hline & & & Anuba & 3763 & 614 & 26 \\
\hline Total & 221 & 18 & & 77,401 & 13,063 & 600 \\
\hline
\end{tabular}

Table 1. Number of sampling districts, peasant associations and informants.

\begin{tabular}{|c|c|c|c|c|c|}
\hline No & Type of Instruments & Target groups & Number of Representations & Type of Sampling & Remark \\
\hline 1 & Key informants Interview & $\begin{array}{l}\text { Long residence and Knowledgeable } \\
\text { community members }\end{array}$ & 90 & Purposive Sampling & Each for PA \\
\hline 2 & Focus group Discussions & Gender group, expert and officials & 36 & Purposive Sampling & Each for district \\
\hline 3 & Household survey & $\begin{array}{l}\text { randomly selected farmers from } \\
\text { households head }\end{array}$ & 600 & Simple random & \\
\hline 4 & Direct field observation & Model field & 24 & Purposive Sampling & 3 for each \\
\hline 5 & Total & & 750 & & \\
\hline
\end{tabular}

Table 2. Summary and descriptions of instruments by type, target and number of target group representations for data collection. 


\subsection{Data Analysis}

Data collected from informants was edited and presented in quantitative terms for analysis using appropriate statistical analysis. Simple quantitative analysis techniques such as percentage and frequency distributions were also employed. Data entry and simple arithmetic calculations were conducted using Excel 2007 and SPSS version 20. Finally the results were summarized in a table form so that the analysis and meaningful interpretations of results was made to draw conclusions and implications. The qualitative data collected through key informant interview, focus group discussion and physical observation was narrated and summarized.

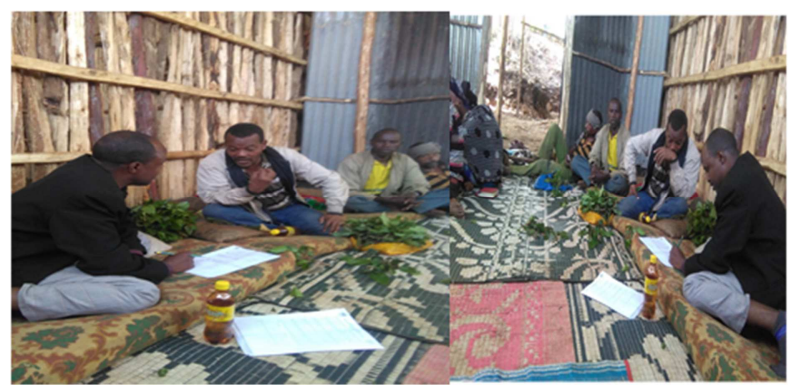

Figure 2. Researcher during focus group discussion.

\section{Results and Discussion}

\subsection{Household Characteristics of Sample Households}

A total of 600 households, comprising 465 male (78\%) and $135(22 \%)$ female were interviewed. Household characteristics of sample households per district are presented in Table three below. Generally, traditional agroforestry practices are mostly done by men because of the cultural values and responsibilities of men in west Hararghe families. As it is clearly seen from Table 3, there appears to be a higher proportion of middle age group household in the study site whereas younger and older households are represented only in smaller portion. Therefore, the study found out that the populations of the surveyed areas were dominated by working age group. According to [12], the national mean household size is 5.1 individuals. Household family sizes tend to influence traditional practices of agroforestry due to the fact that it provides more labour to manage agroforestry practices. The study findings are in consistent with [16] who carried out a study, with and he found out that, large household size positively influences of labor-demanding agriculture like, agroforestry since they have the ability to relax the labor limitations necessary.

Table 3. Household Characteristics of sample households.

\begin{tabular}{|c|c|c|c|c|c|c|c|c|c|}
\hline \multirow{2}{*}{$\begin{array}{l}\text { Socio-economic } \\
\text { variable }\end{array}$} & \multirow{2}{*}{ Definition of variables } & \multicolumn{6}{|c|}{ Sample districts in study site } & \multirow{2}{*}{ Total } & \multirow{2}{*}{$\begin{array}{l}\% \text { of } \\
\text { Respondents }\end{array}$} \\
\hline & & Gemechis & Hancar & Darolabu & Odabultum & Mieso & Burkdhimtu & & \\
\hline \multirow{3}{*}{ Sex } & Male & 100 & 53 & 63 & 89 & 84 & 76 & 465 & 78 \\
\hline & Female & 44 & 11 & 19 & 33 & 17 & 11 & 135 & 22 \\
\hline & Total & 144 & 64 & 82 & 122 & 101 & 87 & 600 & 100 \\
\hline \multirow{4}{*}{ age in year } & $18-24$ & 28 & 17 & 18 & 27 & 22 & 15 & 127 & 21 \\
\hline & $25-54$ & 79 & 35 & 42 & 59 & 61 & 58 & 334 & 55 \\
\hline & $>65$ & 14 & 4 & 4 & 15 & 8 & 6 & 51 & 9 \\
\hline & Total & 144 & 64 & 82 & 122 & 101 & 87 & 600 & 100 \\
\hline \multirow{5}{*}{$\begin{array}{l}\text { House hold } \\
\text { marital status }\end{array}$} & Married & 84 & 50 & 65 & 74 & 64 & 66 & 403 & 67 \\
\hline & Widowed & 13 & 4 & 8 & 13 & 12 & 15 & 65 & 11 \\
\hline & separated/Divorced & 34 & 5 & 3 & 27 & 21 & 5 & 95 & 16 \\
\hline & Single & 13 & 5 & 6 & 8 & 4 & 1 & 37 & 6 \\
\hline & Total & 144 & 64 & 82 & 122 & 101 & 87 & 600 & 100 \\
\hline \multirow{4}{*}{ HH family size } & $<5$ & 46 & 19 & 26 & 47 & 39 & 29 & 206 & 34 \\
\hline & $5-10$ & 94 & 42 & 56 & 73 & 56 & 49 & 370 & 62 \\
\hline & $>10$ & 4 & 3 & 0 & 2 & 6 & 9 & 24 & 4 \\
\hline & Total & 144 & 64 & 82 & 122 & 101 & 87 & 600 & 100 \\
\hline \multirow{6}{*}{$\begin{array}{l}\text { HH educational } \\
\text { back ground }\end{array}$} & Read and write & 43 & 21 & 26 & 38 & 15 & 8 & 151 & 25 \\
\hline & primary first cycle & 35 & 13 & 18 & 28 & 9 & 10 & 113 & 19 \\
\hline & primary second cycle & 8 & 3 & 1 & 7 & 4 & 2 & 25 & 4 \\
\hline & secondary school & 2 & 1 & 3 & 3 & 1 & 2 & 12 & 2 \\
\hline & Not attend any school & 56 & 26 & 34 & 46 & 72 & 65 & 299 & 50 \\
\hline & Total & 144 & 64 & 82 & 122 & 101 & 87 & 600 & 100 \\
\hline
\end{tabular}

Source: Households survey.

\subsection{Socio-economic Characteristics of Sample Households}

The findings indicate that the majority (55\%) of households had stayed in the study site for more than 15 years. The remaining of households (17\%) has stayed for 11-15 years and $16 \%$ for $6-10$ years and $(12 \%)$ have stayed for five year (table 4). Therefore, higher proportion of the sampled household heads at study site was native to the area. The result of the total annual 
income of the respondents was indicated (Table 4). Most respondents are not high income earners and therefore cannot be able to source labor for a fee to manage their agroforestry practices. For this reason they use their family lobour. The study was not similar to [21] who carrying out a study and analyzing factors that affect the implementation of agroforestry practices agrees that income has a positive correlation with agroforestry practices. Most of the farmers who were more likely to practices traditional agroforestry had smaller hectares of land size. Which, is not consistent with [22] an increase of farm size by one hectare, increases the probability of practices agroforestry? It can be indicated that mixed farming was the main type of traditional farming system in study site. Higher proportions of the respondents have livestock number between 1-5 which is manageable around small land and with family lobour (Table 4).

Table 4. Socio-economic Characteristics of sample households.

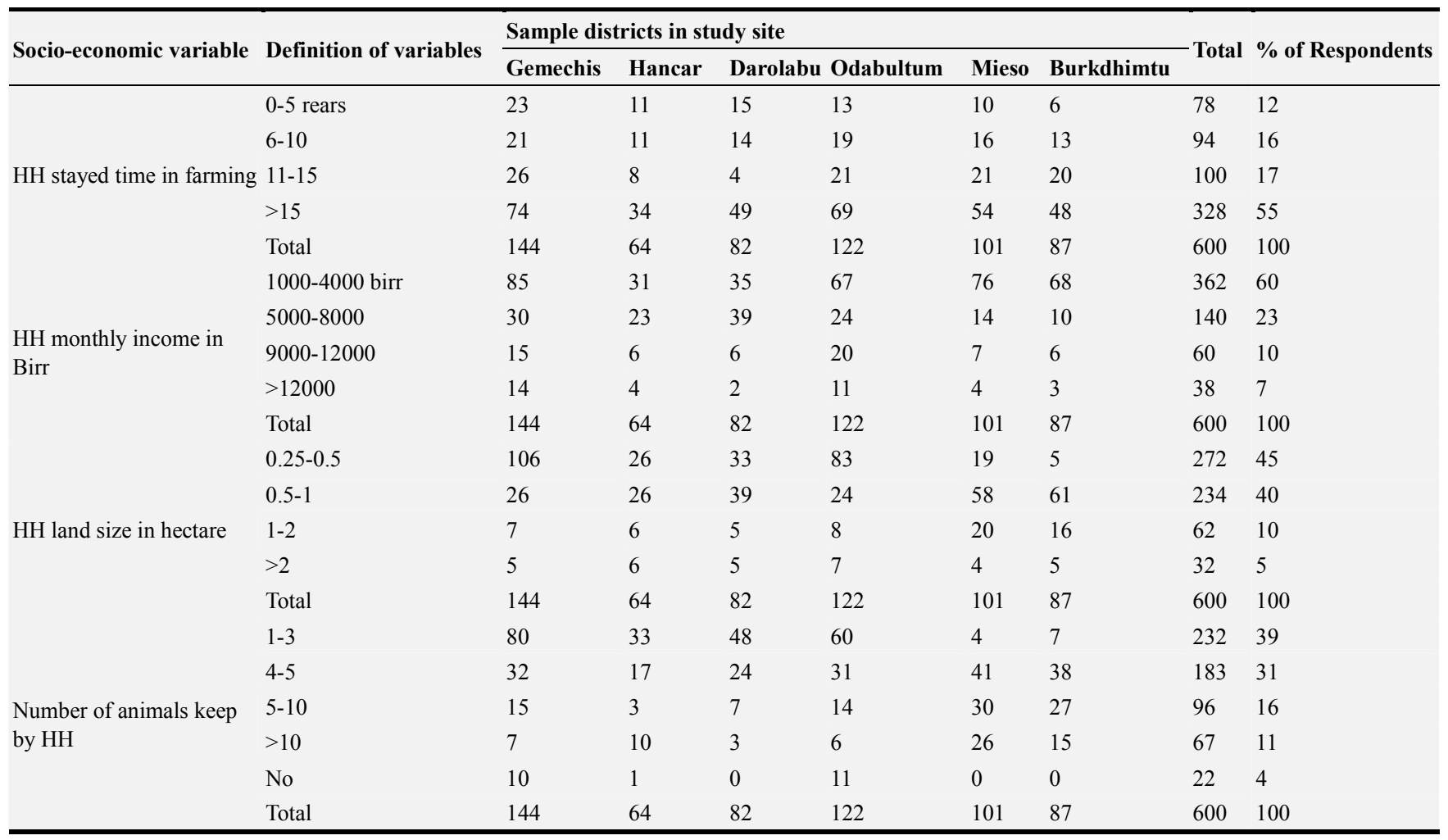

Source: Households survey.

\subsection{Perception About Agroforestry}

Smallholder farmers' current practices of traditional agroforestry practices into their farm plots were recorded through informant interviews. 478 (79.7\%) informants replied verifying the presence of one or some traditional agroforestry practicing on their farm plots, while 122 $(20.3 \%)$ replied that they had no experience of such practices.

In general, the proportion of smallholder farmers with a positive attitude to traditional agroforestry practices on their farm plots is appreciably higher than those who were not clearly and unambiguously positive. Similarly [20] indicated that the combination of several types of products which are both subsistence and income generating, helps farmers to meet their basic needs and minimizes the risk of the production system's total failure. Thus, this practice has reduced the chances of complete crop failure according to the survey conducted in Ethiopia [25] also undertook a survey on traditional agroforestry systems. The large respondents were aware of the benefits of traditional agroforestry practices and had positive attitude towards those practices.

\subsection{Traditional Agroforestry Practiced in Study Area}

Similar to some parts of Ethiopia the following traditional agroforestry practices and varies woody species management were identified in the study area. The result of the study revealed that, among the different traditional of agroforestry practices, Mixed intercropping, is the best preferred one followed by Homegarden, MPTs trees on farmland,Live fence/Boundary planting, Trees in soil conservation/reclamation, Shelter belts and wind breaks, Multipurpose woodlots and Trees on rangeland respectively. Key informants reason out why mixed intercropping is the most preferred traditional of agroforestry practices. Similarly, key informants revealed that next to intercropping they prefer homegarden traditional practices is because of ease for management by old aged people and children who cannot travel and work far away from home. MPTs trees on crop land, provide fuel, building poles, fodder and improve soil fertility, conserve soil moisture and improve the microclimate 
of the area, live fence/boundary planting prefer to protect their land from heavy wind and animal damage.

Table 5. The smallholder farmers reporting their interest in traditional agroforestry practicing in their farm plots in study site.

\begin{tabular}{|c|c|c|c|c|}
\hline \multicolumn{2}{|c|}{ Name of district } & \multirow{2}{*}{$\begin{array}{l}\text { No of Farmers Practiced } \\
115\end{array}$} & \multirow{2}{*}{$\begin{array}{l}\text { No of Farmers Not Practiced } \\
29\end{array}$} & \multirow{2}{*}{$\begin{array}{l}\text { Total } \\
144\end{array}$} \\
\hline \multirow{4}{*}{ Gemechis } & Count & & & \\
\hline & $\%$ within Name of each district & $79.9 \%$ & $20.1 \%$ & $100.0 \%$ \\
\hline & $\%$ within Farmers practicing TAF or not & $24.1 \%$ & $23.8 \%$ & $24.0 \%$ \\
\hline & $\%$ of Total & $19.2 \%$ & $4.8 \%$ & $24.0 \%$ \\
\hline \multirow{4}{*}{ Hancar } & Count & 50 & 14 & 64 \\
\hline & $\%$ within Name of each district & $78.1 \%$ & $21.9 \%$ & $100.0 \%$ \\
\hline & $\%$ within Farmers practicing TAF or not & $10.5 \%$ & $11.5 \%$ & $10.7 \%$ \\
\hline & $\%$ of Total & $8.3 \%$ & $2.3 \%$ & $10.7 \%$ \\
\hline \multirow{4}{*}{ Darollebu } & Count & 66 & 16 & 82 \\
\hline & $\%$ within Name of each district & $80.5 \%$ & $19.5 \%$ & $100.0 \%$ \\
\hline & $\%$ within Farmers practicing TAF or not & $13.8 \%$ & $13.1 \%$ & $13.7 \%$ \\
\hline & $\%$ of Total & $11.0 \%$ & $2.7 \%$ & $13.7 \%$ \\
\hline \multirow{3}{*}{ OdaBultum } & Count & 96 & 26 & 122 \\
\hline & $\%$ within Name of each district & $78.7 \%$ & $21.3 \%$ & $100.0 \%$ \\
\hline & $\%$ of Total & $16.0 \%$ & $4.3 \%$ & $20.3 \%$ \\
\hline \multirow{4}{*}{ Mieso } & Count & 81 & 20 & 101 \\
\hline & $\%$ within Name of each district & $80.2 \%$ & $19.8 \%$ & $100.0 \%$ \\
\hline & $\%$ within Farmers practicing TAF or not & $16.9 \%$ & $16.4 \%$ & $16.8 \%$ \\
\hline & $\%$ of Total & $13.5 \%$ & $3.3 \%$ & $16.8 \%$ \\
\hline \multirow{4}{*}{ Burqadimtu } & Count & 70 & 17 & 87 \\
\hline & $\%$ within Name of each district & $80.5 \%$ & $19.5 \%$ & $100.0 \%$ \\
\hline & $\%$ within Farmers practicing TAF or not & $14.6 \%$ & $13.9 \%$ & $14.5 \%$ \\
\hline & $\%$ of Total & $11.7 \%$ & $2.8 \%$ & $14.5 \%$ \\
\hline \multirow{4}{*}{ Total } & Count & 478 & 122 & 600 \\
\hline & $\%$ within Name of each district & $79.7 \%$ & $20.3 \%$ & $100.0 \%$ \\
\hline & $\%$ within Farmers practicing TAF or not & $100.0 \%$ & $100.0 \%$ & $100.0 \%$ \\
\hline & $\%$ of Total & $79.7 \%$ & $20.3 \%$ & $100.0 \%$ \\
\hline
\end{tabular}

Source: Households survey.

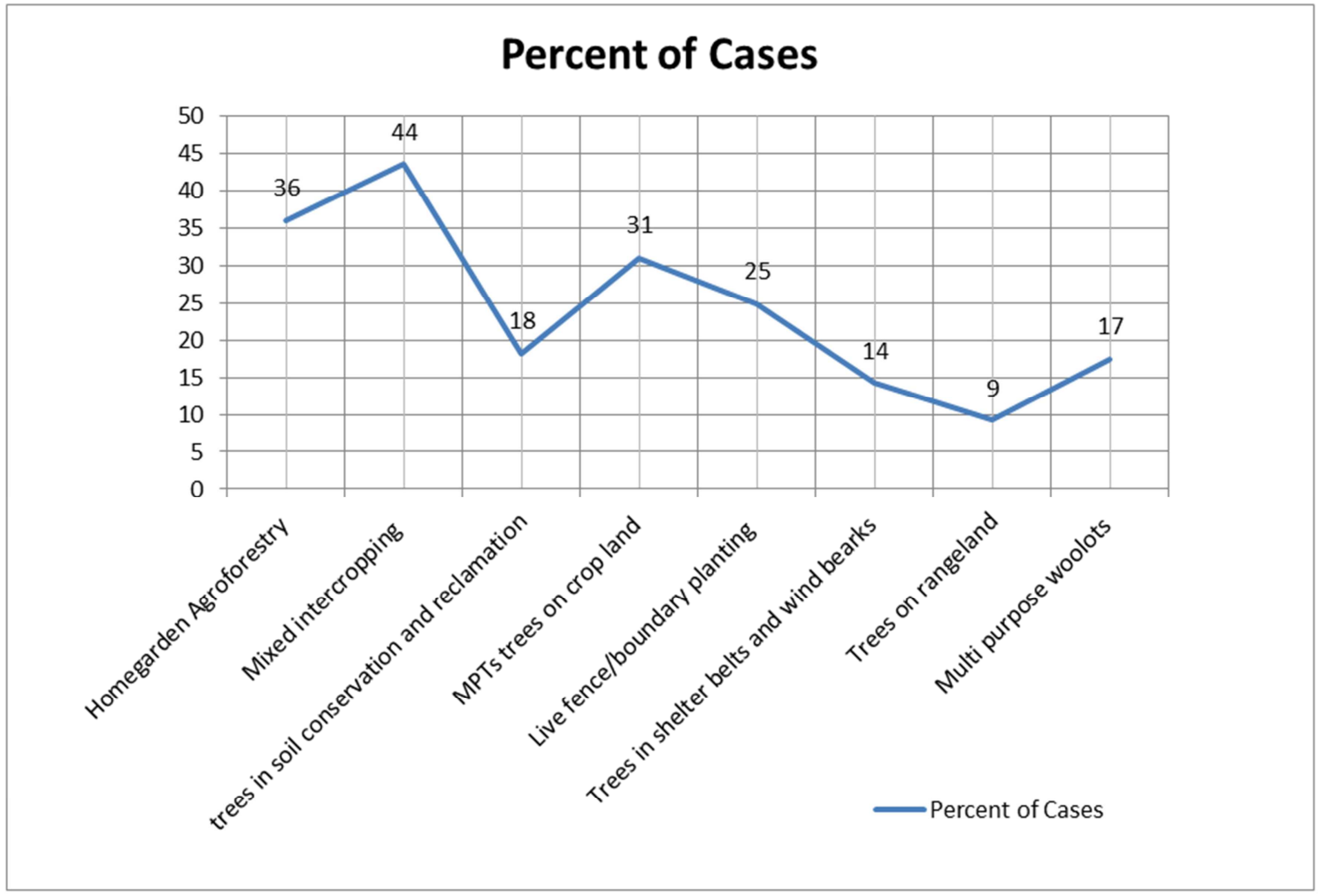

Figure 3. Types of traditional agroforestry practices in study site. 
This figure is in line with reports by [10] the sorghum/maize and chat (Catha edulis) intercropping in the Hararghe Highlands of eastern Ethiopia. The results of the survey by [23], revealed that all sampled respondent were practicing intercropping in the zone.

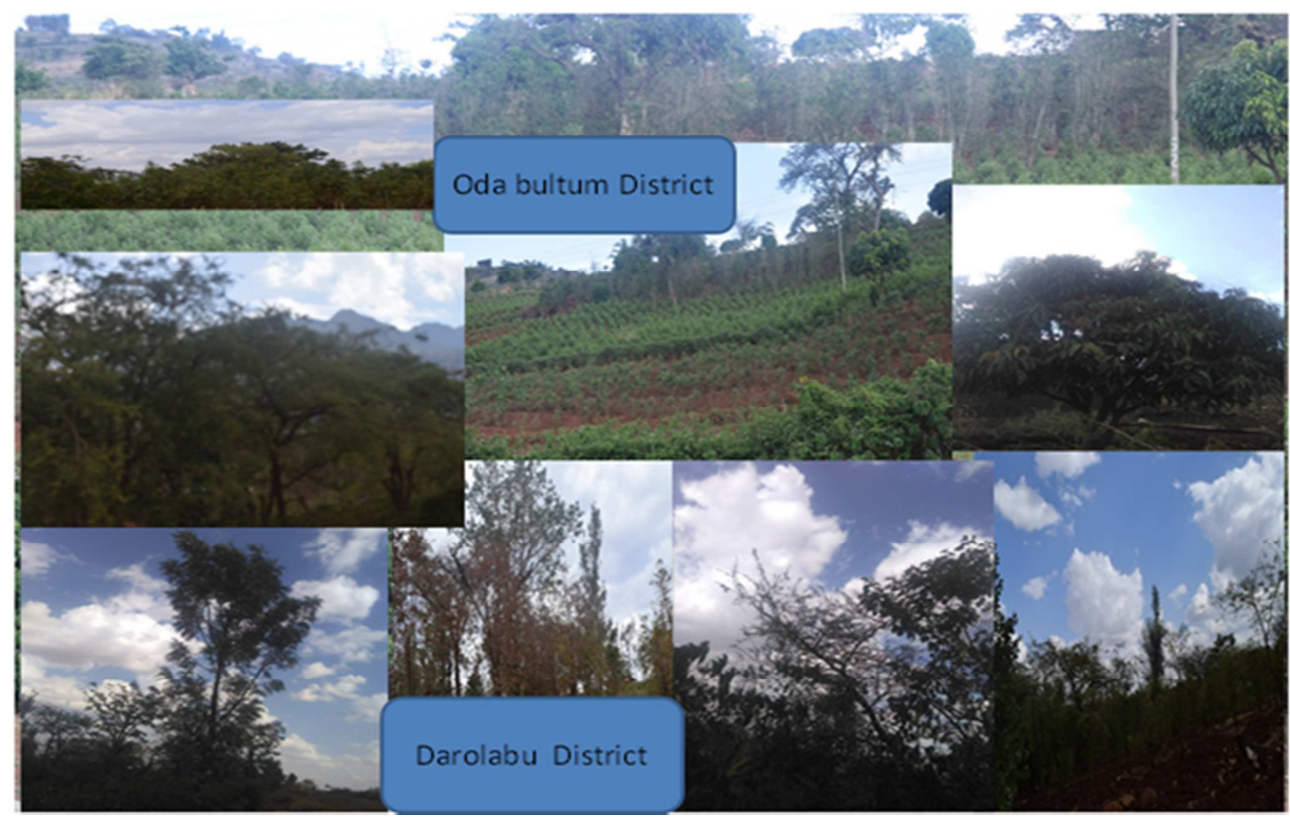

Figure 4. Tress in Mixed intercropping Agroforestry Practices.

\subsection{Farmer's Reasons for Practicing Traditional Agroforestry}

Small holder farmers in the study area have great awareness about the benefits of traditional agroforestry practices. Most of the respondents believe that traditional agroforestry practice is high to enhance the overall productivity. The major reasons and benefits for planting woody species in traditional agroforestry practices in the study area are in the order of its use includes: as Improvement in family income> Improvement in soil quality $>$ Providing variety of food items $>$ Provision of shade by trees $>$ Extraction of trees for fuel wood $>$ Extraction of trees for construction purpose $>$ Manure from animals $>$ Pruning of trees for fodder $>$ Extraction of trees for medicinal purpose (Figure 4).

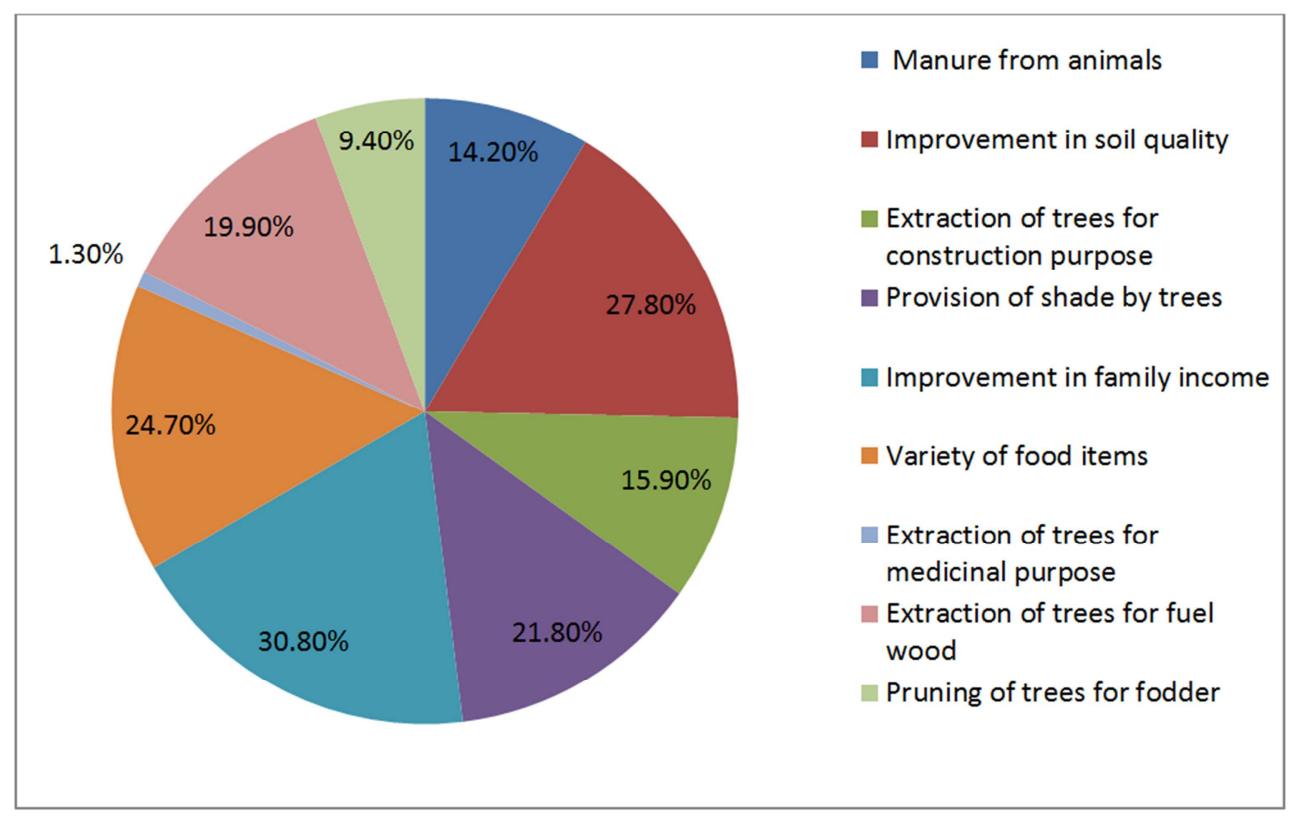

Figure 5. Major reason for farmers practicing traditional agroforestry.

Key informants notified that the uses and benefits they obtain from trees were mentioned as the drive for tree 
retention and planting in the study area. Because of this people in the study area have been accruing diversified uses and services from the trees that were retained and planted in their lands. Among the uses and services are: fuel wood, construction materials, fruit, shade, soil fertility and fodder. Furthermore, in focus group discussions (FGDs) respondents traditional mentioned that they have been obtaining diverse types of benefits from their agroforestry practices. Diversification of income, providing variety of food for household consumption and soil fertility are some of the major benefits that they have been obtaining. Generally, the study has revealed that smallholder farmers in western Hararghe zone have positive attitudes about traditional agroforestry practices, mainly due to the benefits that these practices provide to sustain their life. Income generation is one of most important reasons to practicing traditional agroforestry on farm as most farmers said which was similar to [6] report in northern Ethiopia. The list of uses mentioned by our informants when compared with those reported in many other studies in Ethiopia [14] revealed a high degree of correspondence. The most frequently mentioned purposes for planting and retaining woody species in the traditional agroforestry were also, consistent with the findings of [4] Where, they asserted that tree species were deliberately retained and/or planted on farmlands have served the people for generations by supplying food, fodder, income generation, wood, shade and environmental services.

\subsection{Farmers Perception About Major Constraints for Traditional Agroforestry Practices}

The study disclosed that $122(20.3 \%)$ of 600 informants have no experience of practicing a single traditional agroforestry on their farm plots. (Table 6) presents the major constraints of informants justifying their experiences of not practicing any single traditional agroforestry on their farm plots. A greater proportion of the "no experience" informants presented multiple major constraints to explain why they lacked experience of practicing traditional agroforestry on their farm plots. It will be necessary to wisely and skillfully refute these reasons in order to convince and engage the "no experience" group in activities of on-farm traditional agroforestry management.

Table 6. Major constraints of informants justifying their experiences of not practicing any single traditional agroforestry.

\begin{tabular}{lll}
\hline Major constraints & Frequency & \% of respondents \\
\hline Lack of adequate seedlings availability & 43 & 35 \\
shortage of land for tree planting & 68 & 56 \\
Rainfall shortage & 55 & 45 \\
Termite hazard and disease & 27 & 22 \\
animal browsing and trampling & 37 & 30 \\
shortage of labour & 24 & 20 \\
Inadequate extension agents & 37 & 30 \\
Total & 291 & 238 \\
\hline
\end{tabular}

Source: Households survey.

This is similar with the studies conducted [9] in northeastern Ethiopia. He reported the following challenges to agroforestry in Ethiopia, rights to trees may be separate from rights to land, and both land and tree tenure insecurity may discourage people from continuing long term investments such as agro forestry practices. Several researchers have cited national extension systems in many sub-Saharan African countries such as Ethiopia as a major barrier for scaling -up agroforestry [5]. They note that a lack of rigorous organized and locally adopted extension messages, lack of agroforestry training for extension workers, and unclear assignment of responsibilities of agroforestry between agriculture and forestry extension institutions.

Informants trying to justify their not practicing any single traditional agroforestry on their farm plots proposed very interesting solutions for overcoming the difficulties facing practicing of traditional agroforestry on their farm plots, and a higher number came up with improving extension service of Agroforestry (67\%), improving land tenure policy and provide land for landless individuals $(64 \%)$, providing water harvesting policy and reduce rainfall problems $(62 \%)$ and providing external support like pesticide and other agricultural inputs (53\%). Therefore, informants suggested combinedand multiple solutions compared to those proposing a single solution (see Table 7).

Table 7. Informants'suggestions for overcoming constraints and problems of practicing traditional agroforestry.

\begin{tabular}{lll}
\hline Proposed solutions & Frequency & \% of respondents \\
\hline Improve extension service of AF & 82 & 67 \\
Provide water harvesting policy & 76 & 62 \\
Providing external support and incentives & 65 & 53 \\
Promote traditional rules and enforce & 54 & 44 \\
village bylaw & 34 & 28 \\
Encouraging tree nursery establishments & 34 & 64 \\
Improve land tenure policy and & 78 & 62 \\
provide..... & 32 & 26 \\
Controlling free browsing & 421 & 344 \\
Total &
\end{tabular}

Source: Households survey.

\section{Conclusion and Recommendations}

\subsection{Conclusion}

The active involvement farmers on traditional agroforestry show that they are aware of the value of these practices for their livelihood.

The traditional knowledge on agroforestry system and practice management being applied in the study site should have to get recognition.

Farmers identified a number of uses of the multipurpose species varying degrees of use-values.

Therefore, traditional, agroforestry practice could be one option to improve small farmer's life in study site.

\subsection{Recommendations}

Traditional agroforestry practices were observed, however, identifying representative sites to undertake detailed studies 
on improving existing and introducing new agroforestry systems is needed.

Research should explore the local species that could be of interest to the farmers and help in propagation of seedlings of traditional species which may be of interest to farmers.

Lessons on the usefulness of the local traditional botanical and ecological knowledge and management practices should be included.

Woody tree species in effect on crops yields are not properly documented. Therefore, it is important to study the dominant woody species effect on crop productivity.

The suggestions made to overcome difficulties of practicing traditional agroforestry in smallholders' farm plots have implications for the way forward.

\section{References}

[1] Abebaw, Z. 2006. Farmer's indigenous knowledge in managing agroforestry practices in Lay-Gayint district, south Gonder zone, Ethiopia, Hawssa University, wondogent.

[2] Abebe, Seifu. 2000. Farmers' private tree growing traditions and management at Wondo Genet, M. Sc Thesis, Wagningen University, The Netherlands, pp. 68.

[3] Abera, Worku. 2009. M. Sc. thesis on status of traditional agroforestry and its future Potential development as buffer zone agroforestry for the natural forest conservation in burkitu peasant association, Oromia, Ethiopia. pp 2.

[4] Abiyu, A., D. Teketay, G. Gratzer, and M. Shete. 2015. Tree planting by smallholder farmers in the upper catchment of Lake Tana watershed, northwest Ethiopia. Small-scale Forestry.

[5] Ahmed, P. 1991. Agroforestry: A viable landuse of alkali soils. Agroforestry Systems 14: 23-37.

[6] Arnold, J. E. M. 1987. "Economic considerations in agroforestry" in steppler, H. A. and Nair, P. K. eds. Agroforesty: A Decade of Development. ICRAF, Nairobi, pp. 174-190.

[7] Asfaw, Z. 2001. Origin and evolution of rural homegardens in Ethiopia. Biologiske Skrifter: Danske Videnskabers Selskab 54: 273-286.

[8] Atangana, A., Khasa, D., Chang, S., and Degrande, A. (2013). Major agroforestry systems of the humid tropics. In "Tropical Agroforestry", 49-93.

[9] Berhane Kidane, Mehari Alebachew, Kassahun Bekele, Kindu Mekonnen, Laura A German (2008). Participatory Tree Nursery Management and Tree Planting: Experiences from Gallessa Watershed, Dendi District, Western Shewa zone of the Oromia Region, Ethiopia.

[10] Bishaw, B., and A. Abdelkadir. 2003. Agroforestry and Community Forestry for Rehabilitation of Degraded Watersheds on the Ethiopian Highlands. International Symposium on Contemporary Development Issues in Ethiopia, July 11-12, 2003, Addis.
[11] Christiaensen, L., Demery, L., and Kuhl, J. (2011). The evolving role of agriculture in poverty reduction-an empirical perspective. Development Economics, 96, 239-254.

[12] CSA (Central Statistical Authority), 2007. Population and Housing Census Survey, Addis Ababa, Ethiopia. 121p.

[13] Dechasa, Jiru. 1990. Current Agroforestry Systems in Ethiopia, Proc. 2nd NRC conference, pp 181-185.

[14] Hachoofwe, E. M. 2008. Local ecological knowledge of trees on farms, constraints and opportunities for further integration in Tigray Region, northern Ethiopia: A case study of smallholder farmers in Abreha Wa Atsbeha and Adi gudom. MSc thesis, Te Copperbelt University, Kitwe, Zambia.

[15] Israel, G. D. 2013. Determining sample size. http://edis.ifas.ufl.edu/pdfles/PD/PD00600.pdf.

[16] Kebede, T. M. (2010). Homegardens agrobiodiversity conservation in Sebeta-Hawas Wereda, Southwestern Shewa Zone of Oromia Region, Ethiopia.

[17] Mehari Alebachew (2012). Traditional Agroforestry practices, opportunities, threats and research needs in the highlands of Oromia, Central Ethiopia.

[18] Miller, R. P., and Nair, P. K. R. (2006). Indigenous agroforestry systems in Amazonia: from prehistory to today. Agroforestry Systems 66, 151-164.

[19] Mohammad I, Asadullah K, Mitsuhiro I, Muhammad A, Hassan S (2011) Identifying factors affecting agroforestry system in Swat, Pakistan. African Journal of Agricultural Research, 6: 2586-2593.

[20] Nair, P. K. 1993. An introduction to Agroforestry: pp 13-155, ICRAF/Kluwers Academic Publishers, Dordrecht, The Netherlands.

[21] Negash, M., and N. Achalu. 2008. History of indigenous agroforestry in Gedeo, Southern Ethiopia, based on local community interviews: Vegetation diversity and stucture in the land-use systems. http://agris.fao.org/aos/records/ET2009000185.

[22] Tefera, B., M. L. Ruelle, Z. Asfaw, and B. A. Tsegay. 2014. Woody plant diversity in an Afromontane agricultural landscape (Debark District, northern Ethiopia). Forests, Trees and Livelihoods 23 (4): 261-279. http://dx.doi.org/10.1080/1 4728028.2014.942709.

[23] Tesfaye A. (2005), "Diversity in homegarden agroforestry systems of Southern Ethiopia," Dissertation, Wageningen University The Netherlands, 2005.

[24] WHZBOFED (West Harerghe Zone Finance and Economic Development Office), 2010. Annual Report. 54 p.

[25] World Agroforestry Centre (ICRAF) (2006) Agroforestry for improved livelihoods and Natural resources conservation. An Agroforestry Policy Brief. Kenya, Nairobi. 